\title{
Antinociceptive, antipyretic and anti-inflammatory effects of Clerodendrum phlomidis in mice and rats
}

\author{
D. KILIMOZHI, V. PARTHASARATHY ${ }^{*}$, M. NAGA VENKATA JAYANTH \\ and R. MANAVALAN
}

Department of Pharmacy, Annamalai University, Annamalai Nagar - 608002, Tamilnadu, India.

*Corresponding author, E-mail: vapartha123@gmail.com; Phone: +91-9443512724 Fax: +91-4144-238080

\begin{abstract}
The ethanolic extract of Clerodendrum phlomidis L. belonging to the family of Verbenaceae was evaluated for its antinociceptive, antipyretic and anti-inflammatory activity in mice and rats respectively. Analgesic activity was studied by using acetic acid-induced mouse withering test, hot water tail immersion method and eddy's hot plate method in mice. The antipyretic activity was evaluated against yeast induced pyroxia in rat and anti-inflammatory activity was evaluated by carrageenan-induced hind paw edema and its probable mechanism evaluated in rats. The preliminary phytochemical screening and acute toxicity studies were carried out. $C$. phlomidis extract showed a dose dependent significant reduction of the number of writhes $(\mathrm{P}<0.001)$ with $800 \mathrm{mg} \cdot \mathrm{kg}^{-1}$ body weight dose giving the highest reduction. The extract showed an insignificant elongation of the hot plate reaction time $(\mathrm{P}<0.05)$ and it produced a significant reduction in hot-water tail immersion method. C. phlomidis extract showed significant reduction in brewer's yeast induced hyperthermia in rats. In the carragenan induced paw edema, a dose dependent significant inhibition was observed $(\mathrm{P}<0.001)$ between the $2^{\text {nd }}$ and $5^{\text {th }}$ hr. Preliminary phytochemical screening of the extracts showed that the carbohydrates, proteins, amino acids, phytosterols, alkaloids, fats, fixed oils, flavonoids and gums were present in the plant extract. It is clear that the ethanolic extract of $C$. phlomodis has significant analgesic and anti-inflammatory activity. Inhibition of the synthesis of prostaglandins and other inflammatory mediators probably account for the analgesic and anti-inflammatory properties.
\end{abstract}

(C) 2009 International Formulae Group. All rights reserved.

Key words: $C$. phlomidis, antinociceptive, antipyretic, anti-inflammatory, arthritis.

\section{INTRODUCTION}

Inflammation is a complex pathophysiological process mediated by a variety of signaling molecules produced by leukocytes (Safayhi et al., 1997), especially macrophages (Feldmann et al., 1996; Maini and Taylor, 2000; Kalpan et al., 2002), mast cells (Chen et al., 2000) as well as by the activation of complement factors, which bring about edema formation as a result of extravasations of fluid, proteins and accumulation of leukocytes at the inflammatory site (White, 1999). Various non-steroidal anti-inflammatory drugs (NSAID) are widely used clinically for inflammation and rheumatoid arthritis. However, despite their great number, their therapeutic efficacy seems to be hampered by a number of undesired and often serious side effects. Therefore, it is desirable to find less toxic alternative anti-inflammatory and antinociceptive drugs. Some medicinal plants might be candidates for such alternatives. Indian medicinal plants are a rich source of bioactive substances, which are claimed to induce para-immunity, the non specific immunomodulation of essentially granulocytes, macrophages, and natural killer cells and complement factors (Sainis et al., 1997). 
Clerodendrum phlomidis L. (Family: Verbenaceae) is found in some parts of south India and widely distributed in waste lands. It is a large bush (or) small tree, reaching $9 \mathrm{~m}$ height with more or less pubescent leaves and branches. They grow in mesic habitats with moderate rainfall and mild temperatures (Watsan and Malone 1977; Kaplan, et al., 1987; Ali et al., 1995). The leaves of the plant are used in inflammation. The decoction of the roots and leaves of the herb is used in rheumatism, antimicrobial, (Ahmed et al., 1993), nervous diseases, convalescence of measles, piles, chronic bronchitis (Shan, 1982) etc.

The present investigation was undertaken to study the antinociceptive, antipyretic and anti-inflammatory activities of the ethanolic extract of the leaves of $C$. phlomidis in acute and chronic inflammations.

\section{MATERIALS AND METHODS}

\section{Plant material}

Taxonomic identification of the plant was made from Rapinat Herbarium, St. Joseph's college of arts and sciences, Trichy, Tamilnadu, India (Voucher specimen number $\mathrm{RH} / \mathrm{CP} / 24 \mathrm{~A})$. Whole fresh plant leaves of $C$. phlomidis were collected from Jeyankondam, Perambalur (Dist), Tamilnadu, India. The leaves were dried under shade, segregated, pulverized by a mechanical grinder and passed through 40 mesh sieves.

\section{Preparation of extracts}

The powdered leaves $(500 \mathrm{~g})$ were successively extracted with ethanol $\left(70-80^{\circ} \mathrm{C}\right)$ for $24 \mathrm{hrs}$ by continuous hot percolation method using soxhlet apparatus. The fraction was separated from the solvent by distillation under reduced pressure to yield $5.6 \% \mathrm{w} / \mathrm{w}$ solid mass that was stored in a refrigerator and used for further studies.

\section{Animals}

The animals for the present study were procured after ethical clearance from the Institutional Animal Ethical Committee (IAEC) in Annamalai University, Annamalai nagar, Tamilnadu, India. The animal experiments were carried out according to Committee for the Purpose of Control and Supervision of Experiments on Animals
(CPCSEA) rules. Inbred Wistar rats (150-200 g) were used for testing antipyretic and anti inflammatory activity. The albino mice (20-25 g) were used for testing antinociceptive activity. The animals were housed at the central animal house (Rajah Muthiah Medical College and Hospital, Annamalai University, Tamilnadu, India) under standard conditions of temperature $\left(23 \pm 1{ }^{\circ} \mathrm{C}\right)$, relative humidity $(55 \pm 1 \%), 12 \mathrm{hrs}$ light and dark cycles and fed with standard pellet diet, and tap water ad libitum.

\section{Drugs and chemicals}

All the drugs used in this study were of pharmaceutical grade. Carrageenan was supplied by Sigma chemicals, indomethacine and aspirin were the gift samples from Cadila Pharmaceuticals, Ahamedabad, India. Morphine was supplied by Rajah Muthiah Medical College and Hospital, Annamalai University, Tamilnadu, India.

\section{Preliminary phytochemical tests}

The leaf extract of $C$. phlomidis was subjected to preliminary phytochemical screening, for various active phytochemical constituents such as carbohydrates, steroids, proteins, flavonoids, amino acids, fat, fixed oil, gum and mucilage (Trease and Evans, 1983).

\section{Acute toxicity studies}

Acute toxicity studies were performed (Ecobichon, 1997) according to OECD-423 guidelines (acute toxic class method). Albino mice $(n=3)$ of either sex selected by random sampling technique were employed in this study. The animals were fasted for $4 \mathrm{hrs}$ with free access to water only, after which the extracts were administered orally at the dose level of $5 \mathrm{mg} \cdot \mathrm{kg}^{-1}$ body weight by gastric intubation and observed for 14 days. If mortality was observed in two out of three animals, then the dose administered was considered as a toxic dose. If the mortality was observed only in one mouse out of three animals, then the same dose was repeated again to confirm the toxic effect. If mortality was not observed, the procedure was then repeated with higher dose such as 50, 300 and $2000 \mathrm{mg} \cdot \mathrm{kg}^{-1}$ body weight. 


\section{Antinociceptive activity}

Acetic acid writhing reflex

This was performed according to Gaertner et al. (1999). Albino mice (six per group) were injected intraperitoneally with $0.6 \%$ acetic acid at the dose of $10 \mathrm{ml} . \mathrm{kg}^{-1}$. The extract $\left(200,400\right.$ and $\left.800 \mathrm{mg} \cdot \mathrm{kg}^{-1}\right)$, aspirin (100 mg.kg ${ }^{-1}$ subcutaneously) and distilled water were orally administered $30 \mathrm{~min}$ before the treatment with acetic acid. The writhings induced by the acid, consisting of abdominal constrictions and hind limbs stretchings were counted.

\section{Hot plate method}

The albino mice (20-25 g) were divided into six groups of six animals each. They were initially subjected to $16 \mathrm{hrs}$ fasting and basal reaction time was noted, before the administration of standard drug or test extract (licking of the paws or jumping response) was done at 0 and $10 \mathrm{~min}$ interval. The average of the two readings was obtained as the initial reaction time. The reaction time followed by the administration of the extract or drugs. The animals in group I were administered normal saline (5 ml. $\mathrm{kg}^{-1}$ body weight) orally. The animals in group II (10 mg. $\mathrm{kg}^{-1}$ body weight) treated with morphine sub-cutaneously and the animals in group III, IV, and V were administered the ethanolic extract of $C$. phlomidis at 200 and 400 and $800 \mathrm{mg} \cdot \mathrm{kg}^{-1}$ body weight orally. The hot plate was maintained at $55 \pm 5^{\circ} \mathrm{C}$ (Lanhers et al., 1991). The response was recorded at different time intervals such as $0,1,2,3,4,5$ and 6 hrs after administration of normal saline, standard drug and test extract to the corresponding animal group.

\section{Tail - immersion method}

The albino mice (20-25 g) were divided into six groups of six animals each. They were initially subjected to $16 \mathrm{hrs}$ fasting and basal reaction time was noted before the administration of standard drug or test extract. The animals in group I were administered normal saline ( $5 \mathrm{ml} . \mathrm{kg}^{-1}$ body weight) orally. The animals in group II were administered the standard drug morphine (10 mg. $\mathrm{kg}^{-1}$ body weight) subcutaneously and the animals in group III, IV and V were administered the ethanolic extract of $C$. phlomidis at 200 and 400 and $800 \mathrm{mg} \cdot \mathrm{kg}^{-1}$ body weight orally. The test involved immersing the extremity $(3 \mathrm{~cm})$ of the rat's tail in a water bath containing water at a temperature of $55 \pm 2{ }^{\circ} \mathrm{C}$. Within a few seconds, the rat reacted by withdrawing its tail and the response was recorded at different time intervals such as $0,1,2,3,4,5$ and $6 \mathrm{hrs}$ after administration of normal saline, standard drug and test extract to the corresponding animal groups. The withdrawal of tail from hot water was recorded. Normally the cut of period will be 10 seconds i.e. time of no response was put at $10 \mathrm{sec}$ (Asongalem et al., 2004).

\section{Yeast induced hyperthermia in rats}

Hyperthermia was induced in rats as described by Teotino et al. (1963). The rats were injected subcutaneously with $20 \%$ aqueous suspension of brewer's yeast at a dose of $10 \mathrm{ml} . \mathrm{kg}^{-1}$ body weight of animal and the rectal temperatures were recorded initially and at $18 \mathrm{hrs}$. The animals with an elevation of body temperature at $1{ }^{\circ} \mathrm{C}$ were used for testing the effect of test extract, standard drug and saline control. The animals in group I were administered normal saline $\left(5 \mathrm{ml} . \mathrm{kg}^{-1}\right.$ body weight) orally. The animals in group II were administered the standard drug aspirin (400 mg. $\mathrm{kg}^{-1}$ body weight) orally and the animals in group III, IV and $\mathrm{V}$ were administered the ethanolic extract of $C$. phlomidis at 200, 400 and $800 \mathrm{mg} \cdot \mathrm{kg}^{-1}$ body weight orally after $18 \mathrm{hrs}$ of yeast injection when the temperature increases at its peak. The body temperature was measured at $1 \mathrm{hr}$ intervals up to $3 \mathrm{hrs}$ after administration of plant extracts (Brune and Alpermann, 1983).

\section{Carrageenan-induced paw edema}

The effect of ethanolic extract of $C$. phlomidis in inflammation was tested using a method described by Winter et al. (1962). Rats of either sex were divided into five groups of six animals each. The animals in group I were administered saline $5 \mathrm{ml} . \mathrm{kg}^{-1}$ body weight. The animals in group II were administered indomethacine $\left(10 \mathrm{mg} . \mathrm{kg}^{-1}\right.$ body weight) orally and the animals in group III, IV and $\mathrm{V}$ were administered the ethanolic extract of C. phlomidis at 200, 400 and $800 \mathrm{mg} \cdot \mathrm{kg}^{-1}$ body weight orally $30 \mathrm{~min}$ before the subplanter injection of edematogenic agent. The administration of extracts, saline and drugs were $30 \mathrm{~min}$ prior to the injection of 0.1 
$\mathrm{ml}$ of $1 \%$ carrageenan in saline into the subplanter region of the right hind paw of each rat (Lanhers et al., 1991). The paw volume of the injected animal was measured using a plethysmograph (Ugo Basile, Italy) before and every $1 \mathrm{hr}$ after the injection up to $6 \mathrm{hrs}$.

\section{Statistical analysis}

Data were presented as a mean \pm S.E.M. Stastical difference between control and treated groups were tested by one way ANOVA followed by student's test. The differences were considered significant at $\mathrm{p}<0.05$.

\section{RESULTS}

\section{Acute toxicity}

The leaf extract of $C$. phlomidis didn't show any mortality and toxicity even at highest dose of $2000 \mathrm{mg} \cdot \mathrm{kg}^{-1}$ body weight employed. The present research study was carried out using different doses of ethanolic extract of $C$. phlomidis such as 200, 400 and $800 \mathrm{mg} \cdot \mathrm{kg}^{-1}$ body weight for antinociceptive, antipyretic and anti-inflammatory study.

\section{Antinociceptive effect}

Acetic acid writhing reflex

C. phlomidis significantly reduced writhings and stretchings induced by $0.6 \%$ acetic acid at a dose of $10 \mathrm{ml} \mathrm{kg}$. The significant productive effect was dose dependent with $33.4 \% \quad(p<0.001)$ reduction observed from $200 \mathrm{mg} . \mathrm{kg}^{-1}, 40.5 \%(\mathrm{p}<0.001)$ reduction observed from $400 \mathrm{mg} \cdot \mathrm{kg}^{-1}$ and $34.1 \%$ reduction observed from $800 \mathrm{mg} \cdot \mathrm{kg}^{-1}$. Aspirin (100 mg. $\left.\mathrm{kg}^{-1}\right)$ had only $23.2 \%$ $(\mathrm{p}<0.001)$. The results are shown in figure 1 .

\section{Tail-immersion method}

The ethanolic extract of $C$. phlomidis at the doses of 200, 400 and $800 \mathrm{mg} \cdot \mathrm{kg}^{-1}$ body weight showed significant increase in antinociceptive activity at different time interval such as $0,1,2,3,4,5$ and $6 \mathrm{hrs}$, when compared to the effect produced by normal saline (5 ml.kg ${ }^{-1}$ body weight). The antinociceptive activity produced by the extract of $C$. phlomidis is comparable with the effect produced by standard drug morphine. The results are shown in figure 2. The hot plate method values were insignificant (data not shown).

\section{Yeast-induced hyperthermia in rats}

The ethanolic extract of $C$. phlomidis at the doses of 200, 400 and $800 \mathrm{mg} \cdot \mathrm{kg}^{-1}$ body weights showed significant reductions in the rectal temperature of hyperthermic rats. The decrease in rectal temperature still existed when assessment was made $2 \mathrm{hrs}$ and $3 \mathrm{hrs}$ after test drug administration and efficacy was comparable to that of aspirin at a dose of 400 mg. $\mathrm{kg}^{-1}$ body weight. The results are shown in figure 3 .

\section{Carrageenan- induced paw edema}

The paw volumes and percentages of inhibition by the extract and standard drugs are shown in figure 3. A maximum volume of edema, $1.64 \pm 0.07 \mathrm{ml}(59.22 \%)$ was obtained in 5 hrs. Rats pretreated with C. phlomidis significantly decreased the carrageenaninduced edema $30 \mathrm{~min}$ post dosing at all dose levels used. The extract was more potent at $200 \mathrm{mg} \cdot \mathrm{kg}^{-1}$ as an anti-inflammatory agent than at $400 \mathrm{mg} \cdot \mathrm{kg}^{-1}$. The percentage inhibition for $200 \mathrm{mg} . \mathrm{kg}^{-1}$ ranged from $34.38-62.50 \%$ compared to $400 \mathrm{mg} \cdot \mathrm{kg}^{-1} \quad(16.98-40.63 \%)$ within $5 \mathrm{hr}$. At $800 \mathrm{mg} \cdot \mathrm{kg}^{-1}(26.23 \%$, $\mathrm{P}<0.001)$, the extract and indomethacin (40.68, $\mathrm{P}<0.001)$ attained their maximal protective effects within 5 hrs. Both the extract and indomethacin reduced the swellings. The results are shown in figure 4 .

\section{DISCUSSION}

Induction of inflammation by carrageenan involves 3 distinct phases of mediator release. The first phase involves the release of histamine and serotonin and last between the first to the second hr, the second phase is the release of kinins lasting from the second to the third hr while the third phase involves the release of prostaglandins and lasts from the third to the fifth hr (Surender and Mafumdar, 1995). Thus, it can be inferred 


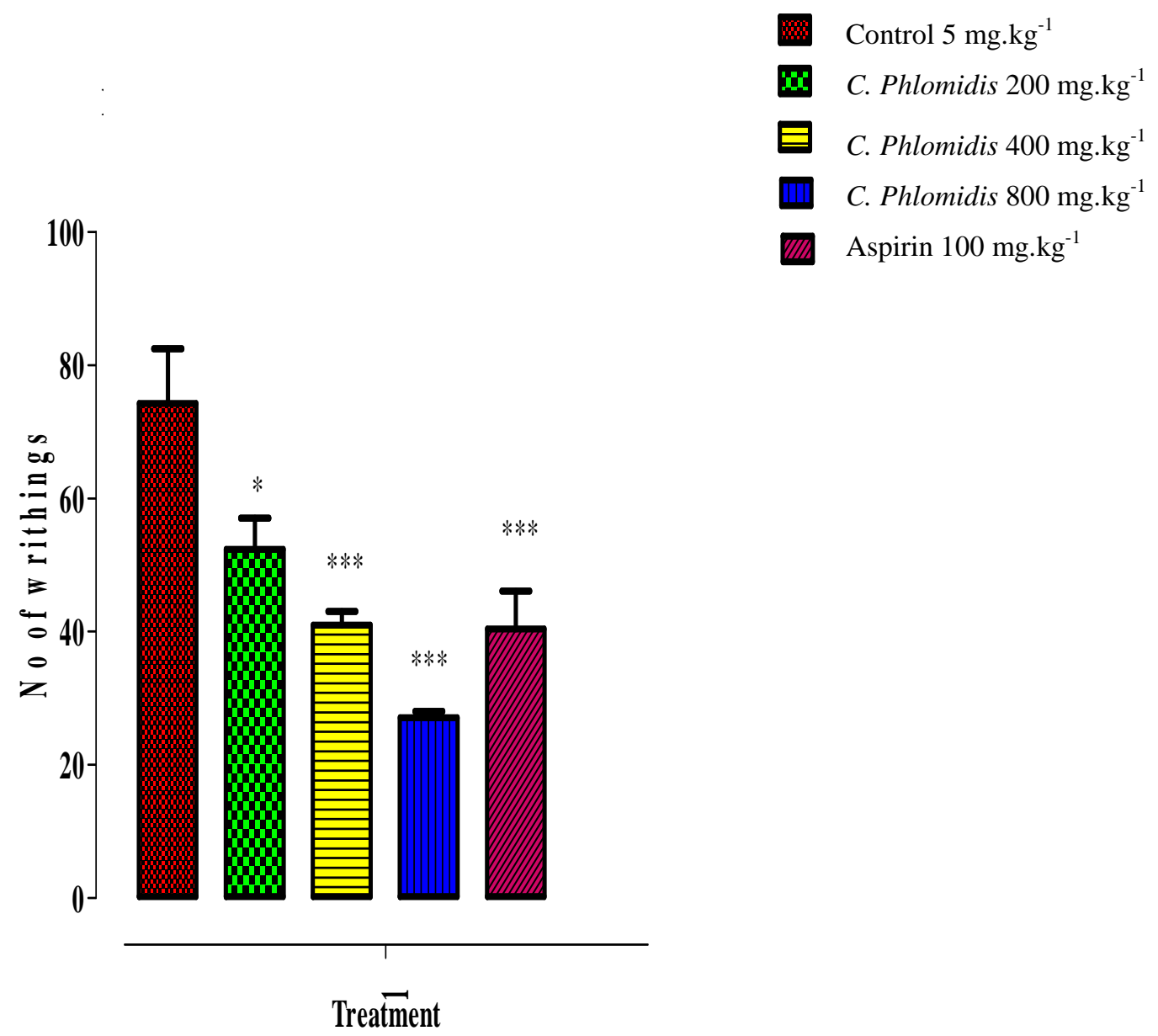

Figure 1: The antinociceptive effect of ethanolic extract of C. Phlomidis (200, 400 and $800 \mathrm{mg} \cdot \mathrm{kg}^{-1}$ body weight), tested by acetic acid writhing test using mice. Aspirin $\left(100 \mathrm{mg} \cdot \mathrm{kg}^{-1}\right)$ was used as a standard drug. The control animal was given normal saline $\left(5 \mathrm{ml}^{\mathrm{k}} \mathrm{kg}^{-1}\right)$. The antinociceptive effect was counted within $30 \mathrm{~min}$. Each value represents mean \pm S.E.M, $\mathrm{n}=6$. The statistical analysis was carried out using one way ANOVA method, where $* * * \mathrm{P}<$ 0.001 .

that the mechanism through which the extract elicits its effects is via the inhibition of the synthesis of kinins and prostaglandins, since the extract was effective at these phases of mediator release. The extract's antiinflammatory effect was dose dependent with $400 \mathrm{~m} / \mathrm{kg}$ body weight dose giving the highest percentage inhibition. When compared with the standard reference drug, indomethacin (10 $\mathrm{mg} / \mathrm{kg}$ ) the percentage inhibition produced by the extract was $98 \%$ at the second $\mathrm{hr}, 94.8 \%$ at the third hr and $85 \%$ of that of indomethacin at the fifth hr (results not shown). Its effects were, however, higher at the $30^{\text {th }} \mathrm{min}$, first and fourth $\mathrm{hr}$ as the percentage inhibition produced by the extract was $156.8,112.6$ and
$105.6 \%$ that of indomethacin, respectively (result not shown). This data thus provides pharmacological basis for the use of this plant in the treatment of rheumatism and other ailments in which inflammation is implicated (Watt and Breyer-Bradwijk, 1962).

Inhibition of acetic acid-induced writhing in mice suggests that the analgesic effect of the extracts may be peripherally mediated via the inhibition of the synthesis and release of prostaglandins (Koster et al., 1959). Writhes can be described as a wave of constriction and elongation passing gradually along the abdominal wall with twisting of the trunk and extension of the hind limbs in mice. This is due to the nociceptive property of 
Table 1: Inhibitory effects of the extract and indomethacine on carrageenan-induced paw oedema.

\begin{tabular}{|c|c|c|c|c|c|c|c|}
\hline \multirow{2}{*}{ Treatment } & \multirow{2}{*}{$\begin{array}{l}\text { Dosage } \\
(\mathrm{mg} / \mathrm{kg})\end{array}$} & \multicolumn{6}{|c|}{ Percentage inhibition } \\
\hline & & $1 \mathrm{hr}$ & 2 & 3 & 4 & 5 & 6 \\
\hline Indomethacine & 10 & $21.87 * *$ & $21.74 * *$ & $40.68 * * *$ & $22.41 * *$ & $39.34 * * *$ & $33.96 * *$ \\
\hline Extract & 200 & $62.50 * * * *$ & $50.0 * * *$ & $42.44 * * *$ & $43.01 * * *$ & $54.10 * * *$ & $47.17 * * *$ \\
\hline Extract & 400 & $28.12 * *$ & $21.74 * *$ & $18.64 * *$ & $20.69 * *$ & $39.34 * * *$ & $16.98^{*}$ \\
\hline Extract & 800 & $9.38 *$ & $10.87 *$ & $18.64 * *$ & $13.79 *$ & $26.23 * *$ & $24.53 * *$ \\
\hline
\end{tabular}

Values are mean percentage inhibitions of oedema in both the extract and indomethacin treated groups ( $\mathrm{n}=6$ per group). $* \mathrm{P}<$ 0.05. ** $\mathrm{P}<0.01$. *** $\mathrm{P}<0.001$. **** $\mathrm{P}<0.0001$.

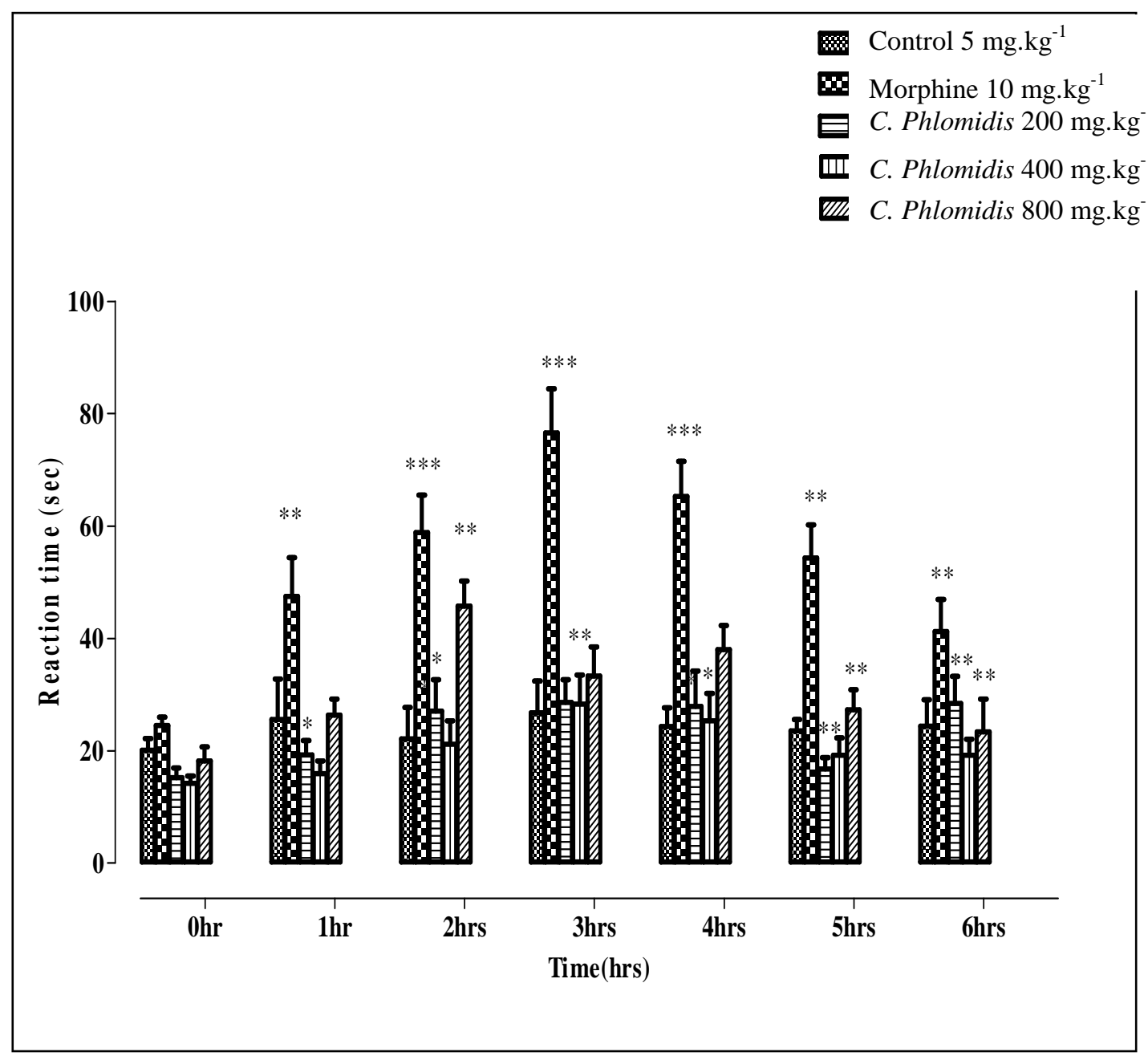

Figure 2: The antinociceptive effect of ethanolic extract of C. phlomodis (200, 400 and $800 \mathrm{mg} \cdot \mathrm{kg}^{-1}$ body weight), tested by hot water tail-immersion method using mice. Morphine $\left(10 \mathrm{mg} \cdot \mathrm{kg}^{-1}\right)$ was used as a standard drug. The control animal was given normal saline $\left(5 \mathrm{ml} \cdot \mathrm{kg}^{-1}\right)$. The antinociceptive effect was tested at different time interval such as $0,1,2,3,4,5$ and 6 hrs. Each `value represents mean \pm S.E.M, $n=6$. The statistical analysis was carried out using one way ANOVA method, where $* * * \mathrm{p}<0.001$. 


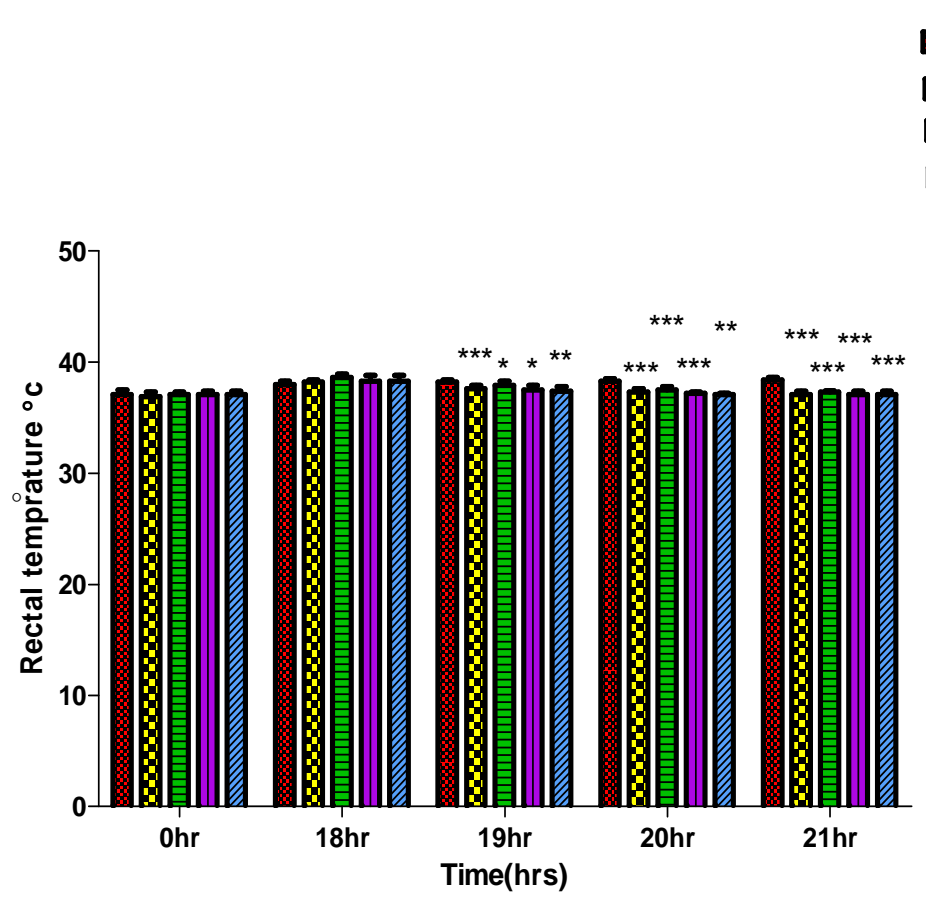

Figure 3: The antipyretic effect of ethanolic extract of $C$. phlomidis $\left(200,400\right.$ and $800 \mathrm{mg} \cdot \mathrm{kg}^{-1}$ body weight), tested by brewer's yeast induced pyroxia in rats. Aspirin (400 mg. $\mathrm{kg}^{-1}$ body weight) was used as a standard drug. The control animal was given normal saline $\left(5 \mathrm{ml} . \mathrm{kg}^{-1}\right.$ body weight). The antipyretic effect was tested at different time interval such as $0 \mathrm{hr}, 18 \mathrm{hrs}, 19 \mathrm{hrs}, 20 \mathrm{hrs}$ and $21 \mathrm{hrs}$. Each value represents mean \pm S.E.M, n=6. The statistical analysis was carried out using one way ANOVA method, where *** $\mathrm{P}<0.001$.

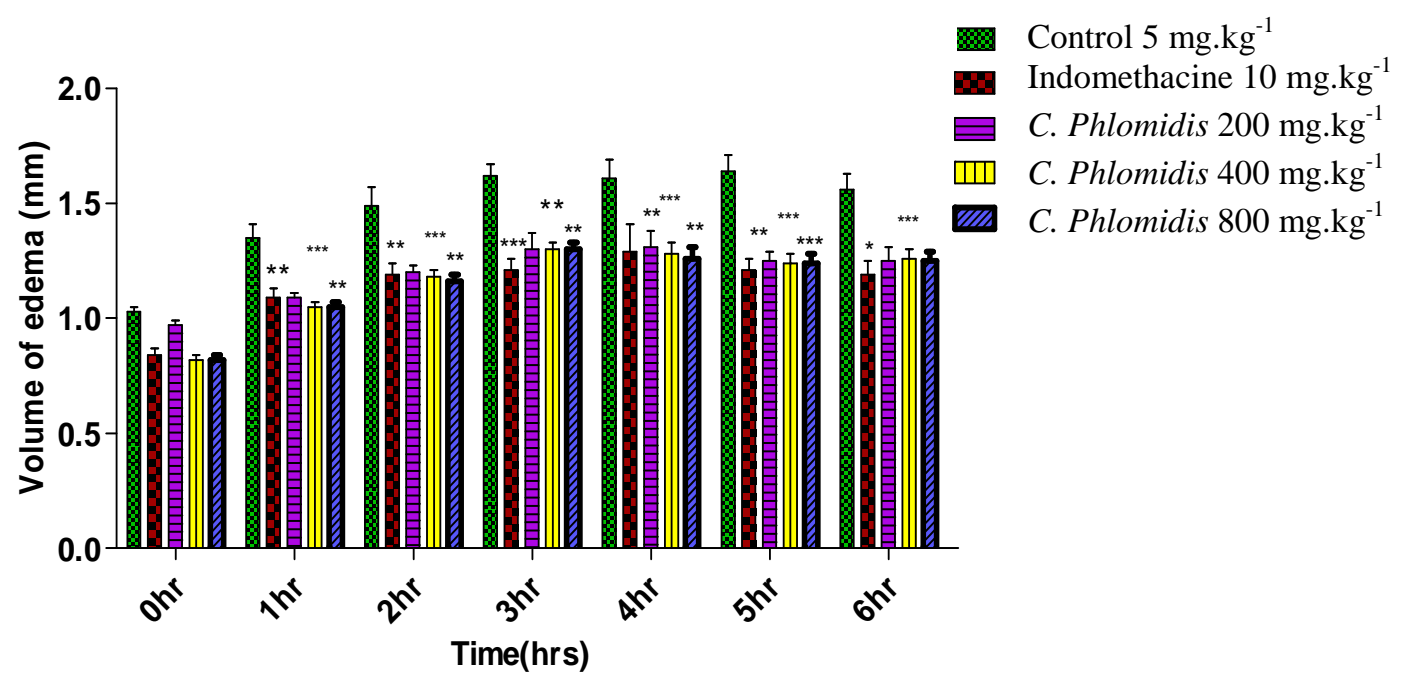

Figure 4: The anti-inflammatory effect of ethanolic extract of C. phlomidis (200, 400 and 800 $\mathrm{mg} . \mathrm{kg}^{-1}$ body weight) against carrageenan-induced paw edema in rat. Indomethacine $\left(10 \mathrm{mg} \cdot \mathrm{kg}^{-1}\right.$ body weight) was used as a standard drug. The control animal was given normal saline (5 mg. $\mathrm{kg}^{-1}$ body weight). The antiinflammatory effect was tested at different time interval such as 1, 2, 3, 4, 5and 6 hrs. Each value represents mean \pm S.E.M, $\mathrm{n}=6$. The statistical analysis was carried out using one way ANOVA method, where $* * * \mathrm{P}<0.001$. 
acetic acid (Surender and Mafumdar, 1995). The percentage of inhibition, clearly shown in Table 1, also indicates that the extract at 400 and $800 \mathrm{mg} \cdot \mathrm{kg}^{-1}$ produced a higher inhibition when compared to aspirin (100 mg. $\left.\mathrm{kg}^{-1}\right)$, a known standard analgesic drug. The inhibitory effect was 139 and $124 \%$ of the effect produced by aspirin at 200 and $400 \mathrm{mg}$ doses, respectively (result not shown).The extract failed to increase mice reaction time on hot plate. The difference between the mean reaction time of the $C$. phlomidis treated groups and the control group was not statistically significant at all doses tested. Its effect was not comparable to morphine, which had a mean reaction time of above $2 \mathrm{~min}$, which was the cut off point $(p<0.0001)$. The analgesic effect of the leaf extract of $C$. phlomodis has not been previously reported and the mechanism by which it occurs is most likely via the inhibition of prostaglandin synthesis as indicated by the inhibition of acetic acid-induced mouse writhing. The ethanolic extract of $C$. phlomidis produces significant reduction on tail-immersion method. Also, it is known that centrally acting analgesic drugs elevate the pain threshold of mice towards heat and pressure (Adeyemi et al., 2003). From the above findings, the extract failed to raise the pain threshold on the hot plate, which indicates that it might not be centrally acting. The extract of C. phlomidis produces significant reduction on tail-immersion method and it seems to possess analgesic properties, which are mediated via peripheral inhibitory mechanisms.

The antipyretic activity of the extract was expected since from the antiinflammatory and analgesic tests, the extract was consistently shown to act peripherally on inflammatory mediators especially prostaglandins. The blockade of phase 2 of formalin test was typical of substances, which antagonize cyclo-oxygenase - an enzyme which produces prostaglandins responsible for the genesis of fever (Brune and alpermann, 1983).

\section{Conclusion}

The ethanolic extract of Clerodendrum phlomidis has anti-inflammatory, peripheral analgesic and antipyretic properties on acute and possibly chronic inflammatory processes. The claim made by tradipractitioners (Adjanohoun et al., 1996) that Clerodendrum phlomidis can be used to treat various pains and inflammatory diseases is founded.

\section{REFERENCES}

Adeyemi OO, Okpo SO, Okpaka O. 2004. The analgesic effect of the methanolic extract of Acanthus motanus. J. Ethnopharmacol., 90: 45.

Adjanohoun JE, Aboubakar N, Dramane K, Ebot ME, Ekpere JA. 1996. OAU/STRC Traditional medicine and Pharmacopoeia: Contribution to Ethnobotanical and Floristic Studies in Cameroon. CNPMS: Porto Novo, Benin; 360-420.

Ahmed M, Jain N. 1993. Two new flavones glycosides from the leaves of $C$. phlomidis. Journal of Chemistry Research, 45: 248-250.

Ali BH, Bashir AK, Tanira MO. 1995. Antiinflammatory, anti-pyretic and antinociceptive effects of Lawsonia inermis L. (Henna) in rats. Journal of Pharmacology, 51: 356-363.

Brune K, Alpermann h. 1983. Non-acidic inhibition of prostaglandin production, carrageenan oedema and yeast fever. Agent Actions, 13: 360-363.

Chen H, Ikeda U, Shimpo M, Shimda K. 2000. Direct effects of stain on mast cell primarily involved in arthroscheloresis. Hypertension Research, 23: 187-192.

Crunkhon P, Meacock SER. 1971. Mediators of the inflammation induced in the rat paw by carrageenan. British Journal of Pharmacology, 42: 394-402.

Ecobichon DJ. 1977. The Basis of Toxicology Testing. CRP Press: New York; 43-86.

Feldmen M, breenan FM, Foxwell BM, Maini RN, 1996. Role of cytokines in rheumatoid arthritis. Annual Review of Immunology, 14: 397-440.

Gaertner M, Muller L, Roos JF, Cani G, Santos ARS, Niero R, Calixto JF, Yunes RA, Delle Monache F, Cechinel-Fehho V. 1999. Analgesic triterpenes from Sebastiania schottianan roots. Phytomedicine, 6: 41-44.

Kalpan C, Valdez JC, Chanderasekaran R, Eibal H, Mikecz K, Glant T, Finnegan A. 2002. The cytokines regulate 
priteoglycon-specific antibody isotypes and arthritis. Arthritis Reference, 4: 5458.

Kalpan HR, Wolke RE, Malone MH. 1967. Anti-inflammatory evaluation of cryogenin. Journal of Pharmaceutical Sciences, 56: 1385-1392.

Koster R, Anderson M, De Beer EJ. 1959. Acetic acid for analgesic screening. Fed. Proc., 18: 418-420.

Lanhers MC, Fleurentin J, dorfman $\mathrm{p}$, Moitrier F, Pelt JM. 1991. Analgesic, antipyretic and Anti-inflammatory properties of Euphorbia hirta. Planta Medica., 57: 225-231.

Maini RN, Taylor PC. 2000. Anti-cytokine therapy for rheumatoid arthritis. Annual Review of Medicine, 51: 207- 229.

Safahyi H, Rall B, Sailet ER, Ammon HPT. 1997. Inhibition by boswellic acids human leukocyte. Journal of Pharmacology Experimental Therapeutics, 281: 460-463.

Sanish KB, Sumariwalla PF, Goel A, Chintalwar GJ, Sipahimalani AT, Banerji A. 1997. Immunomodulatory properties of Tinospora cardifola: Cell targets and active principles. In Immunomodulation, Upadhya SN (ed). Narosa publishing house: New Delhi, India; 93-101.

Shah NC. 1982. Herbal Folk medicines in Northern-India. Journal of Ethanopharmacology, 6: 293-301.

Singh GB, Singh S, Bani S, Gupta BD, Banergee SK. 1992. Anti-inflammatory activity of oleic acid in rats and mice. Journal of Pharmacology, 44: 456-458.

Surender S, Mafumdar DK. 1995. Antinociceptive activity of Ocimum sanctum and its possible mechanism of action. Journal of Pharmacognosy, 33(3): 188-192.

Teotino UM, Friz IP, Gandini A, Bella DD. 1963. Thioderivative of 2-3-dihydro-4H1, 3-benzoxazin-4-one synthesis and pharmacological properties. Journal of Medicinal Chemistry, 6: 248-250.

Trease GE, Evans WC. 1983. Pharmacognosy. Bailliere Tindall Press: London; 309-706.

Vinegar R, Schreiber WR. 1969. Biphasic development of carrageenan edema in rats. Journal of Pharmacology Experimental Therapeutics, 166: 96-103.

Walt JM, Breyer-Bradwijk MG. 1962. The Medicinal and Poisonous Plants of Southern and Eastern Africa. Livingstone: London; 52.

Watson WC, Malone MH. 1977. Evaluation of Ali B. H. immunosuppressive potential of cryogenine using developing and established adjuvant arthritis in rats. Journal of Pharmaceutical Sciences, 66: 1304-1308.

White MJ. 1999. Mediator for inflammation and inflammatory process. Journal of Allergy Clinical Immunology, 103: S378S381.

Winter CA, Risely EA, Nuss GW. 1962. Carrageenan-induced edema in the hind paw of the rat as an assay for antiinflammatory drugs. Proceeding Social Experimental Biological Medicine, 111: 544-547.

Young H, Luo Y, Cheng H, Hsieh W, Liao J, Peng W. 2005. Antinociceptive and Antiinflammatory activities of (6)-gingerol. Journal of Ethanopharmacology, 96: 207-210. 